This is the accepted manuscript of the following article: Palacios, M., Translation in the feminine: Theory, commitment and (good) praxis, Women's Studies International Forum (2013), http://dx.doi.org/10.1016/j.wsif.2013.06.003.

(C) 2014 Elsevier B.V. This manuscript version is made available under the CC-BY-NC-ND 4.0 license (http:// creativecommons.org/licenses/by-nc-nd/4.0/)

\title{
Translation in the feminine: Theory, commitment and (good) praxis
}

\section{Manuela Palacios}

University of Santiago de Compostela, Facultade de Filoloxía, Avda. Castelao s/n, 15782 Santiago de Compostela, Spain

\section{Sinopsis}

The gap between translation theory and practice can be narrowed by means of translators' selfreflections on their practice, although they need to acknowledge the specificity of their standpoint and avoid speaking from a transcendent position. This article engages in such selfreflective practice in order to denounce the strategies of stigmatization of feminist translation in the patriarchal defense of national culture and literary tradition. The nascent translation industry in Galicia is still marred by a bad praxis that exposes the power imbalance among the various actors involved in the translation process. Also, the introduction of the gender variable in the debate around the tensions between professional translators and amateurs reveals interesting loci of alternative practices. A plurality of translation actors, each of them enjoying some relative autonomy regarding their audience and objectives, seems more appropriate than a translation industry controlled by one, no matter how enlightened, single caucus.

\section{Introduction. Feminist translation: anxiety and resistance}

Over twenty years ago, Barbara Godard (1988) encouraged translators to reflect publicly on their experience and on the principles that sustained it ( $p .51)$. The goal of this self-reflective strategy was to put an end to the process of concealment which, from a variety of institutions, successfully pursued to minimize the public relevance of the translator's intervention. For this reason, I have always tried to follow Godard's recommendation and have accompanied my translations with this self-reflective exercise with the aim of bringing theoretical proposals and translation practice more closely-especially since the latter is often perceived as lagging behind (Arrojo, 1998; Castro, 2010, pp. 465-468). However, I would not like to privilege theoretical debate, because theory and practice should definitely inform each other, even if they do not seem to keep the same pace. It is by now widely acknowledged that theory necessarily underlies all translation practice, even when translation actors seem unaware of its doing so (Wagner \& Chesterman, 2002), but theory is not an unquestionable source of wisdom that practice merely illustrates. Consequently, we should strive to find out the ways in which practice can inform and, if necessary, interrogate theoretical tenets.

In this essay, I will part from some fundamental notions in feminism and translation theory which unveil the mechanisms of resistance to feminist interventions in translation. I will then proceed to discuss the ideological struggles within the Galician cultural milieu in which I workGalicia is a semi-autonomous community in the North-West of Spain - where tensions between the national and the feminist on the one hand and the amateur and the professional on the other reveal some glaring power imbalances but also let us glimpse some possible loci of resistance. Finally, I will discuss my own experience as a translator and editor of translations in 
the context of the aforementioned tensions. Self-reflective practice should start by explaining who speaks and from where. Circumscribing our point of view reveals the subjectivity of our considerations and the specificity of time and place in our statements. I leave to others the attempt to analyze the act of translation objectively, to transcend, if they can, the ideological frame and the circumstances that constrain their experience. As far as I am concerned, I cannot-and think I should not-speak from that transcendent position of alleged objectivity. I even think it is of great interest and urgency to unmask the partiality of those humanist discourses which present themselves as objective, fixed and common-sense truths because, as Catherine Belsey (1980) has argued, common sense is discursively constructed at each historical moment and within each particular social formation (pp. 1-7). As a woman translator, I have been following the increasing production of research, particularly since the 1980s, on the intersection of translation and gender. Scholars have tried to recuperate women's translations, which had been forgotten or even lost, they have traced genealogies of women translators and have studied the labor conditions of these women at different times in history (Delisle, 2002). Research has also identified those texts by women authors which have been rendered in translation and has analyzed the ways in which translation contributes to these authors' reception beyond their frontiers. Thus, for instance, Zaragoza Ninet (2008) and Godayol (2011) have traced the Spanish reception of foreign women writers through translation and their impact on the various literary systems in Spain. Conversely, Miguélez-Carballeira (2004) has scrutinized the frictions between literary criticism and translation and how they affect the AngloAmerican reception of a number of women writers from Spain. Although this kind of studies may seem limited to gynocritics - an approach concerned with literary works and translations made by persons of the female sex-the biological marker of woman has such social and ideological repercussions that whatever is natural in it is soon enveloped, and even overridden, by what is cultural, i.e. the construction of woman that social groups have elaborated according to the dominant criteria at each particular time. Elaine Showalter (1985) explains gynocritics as follows: I suggest that the study of women's writing and female creativity, which I call "gynocritics," offers the most exciting prospect for a coherent feminist literary theory, and the opportunity to break away from dependency on male models in forging a criticism of our own (p. 12). Gynocritics has been accused of essentialism (Weedon, 1987, p. 156), because it has based its methodology of corpus choice on the biological category of woman and because it runs the risk of homogenizing and fixing what is necessarily plural and changing. Bearing these caveats in mind, however, I believe we can still engage in a gynocritical approach as long as we are attentive to the convoluted intersections of biology and culture, and avoid re-inscribing universal and transcendent subjectivities. I therefore agree with Luise von Flotow (2011) when she claims that one can recuperate the term woman and bring back with it the still necessary social and cultural activism of the feminist movement in the 1980s and 1990s (p. 1). I speak as a woman, although I am conscious that, historically, it has not been easy for women to draw attention to their work, to expose it to view, to reflect upon it publicly, or even to get for it the recognition it deserves. To Lori Chamberlain's (1988) discussion of the metaphors that identify woman and translation, in particular those about the fidelity contract that binds them and their mere reproductive function, we should add the fact that femininity has been socially construed as, among other qualities, modesty and discretion, and it is at this point where gender and translation again converge (Nikolaidou \& López Villalba, 1997, p. 93). Both woman and translation are expected to pass unnoticed for the sake of a superior good: the male, the family or the nation in woman's case; in the case of translation, for the sake of the original creation or the dominant ideology among the reading public. For this reason, a female translator's selfreflective practice becomes doubly destabilizing, since it defies expectations regarding both 
gender and genre, i.e. that, as a woman, she should be modest and not draw attention to herself and that her intervention in the translation process should be invisible. The theoretical scope of her self-reflection will maximize her defiance of the gender-genre conventions because, as Mary Daly (1985) has denounced, theory has traditionally been in male hands. Since Daly's complaint, there have been a growing number of women thinkers and translation theoreticians with the capacity to speak, though not always to be heard. I perceive there is still a dearth, however, of women translators who elaborate on their translating experience. Apart from paying attention to translations of womenauthored texts and to women translators and their work, translation studies have registered the impact of feminist analyses both on translation theory and on its practical manifestations. Sherry Simon has highlighted the difference between the relevance of the gendered identity of the translator and the influence on the politics of literary transmission of the ideological project promoted by the translator (1996, pp. viii-ix). In line with Simon's observation, current debates are not just about the category woman or feminine, but also feminist, thereby moving beyond biological markers and their cultural implications in order to actively intervene in an ideological confrontation with patriarchy. The aim of this intervention is not just to correct imbalances and promote equal opportunities for men and women, but to dismantle the oppressive principles which sustain patriarchy (Moi, 1989). Reached this point, I must again be clear about my standpoint and say that I am speaking as a feminist-or at least I aspire to be one, unafraid of adopting this category in spite of its stigmatization. By patriarchy 1 mean an ideology that defends the values and interests of a dominant group which has, throughout history, mainly consisted of men. Actually, the third definition of patriarchy in the OED (2005) is: "The predominance of men in positions of power and influence in society, with cultural values and norms being seen as favoring men. Freq. with pejorative connotation". However, patriarchy oppresses both other men in subaltern positions and women, and I must add that patriarchy has sought and found complicities among those it oppresses. Thus, many women have supported and perpetuated patriarchy either because they thought they could derive some material or symbolic benefit from doing so or because, in their helplessness before patriarchal institutions, they opted for yielding to them. Thus, for instance, in her discussion of the oppression of women by the Irish patriarchal nation, Gerardine Meaney (1993) denounces that women, rather than passive bystanders, have often been implicated in their own oppression for their involvement in violent and prejudiced sectarian fights (p. 238). With my emphasis on the ideological dimension of patriarchy, I want to look beyond the mere malefemale binary opposition. Also, I find it especially useful to supplement those analyses based on the oppressor-oppressed paradigm with more complex positions such as oppressed, though unaware of the oppression suffered, or oppressed, but complicit in that oppression or, of particular interest for my argument later in this essay: oppressor, though fearful. Regarding patriarchy's fears, I would like to refer to Virginia Woolf's ([1929]1992, p. 7) essay A Room of One's Own, in which the narrator describes the beadle's "horror and indignation" as the visiting woman steps on the Oxbridge university lawn. If patriarchy has all the power, why is it horrified and angry? She asks (p. 42). Anger is concomitant with power because, as Rachel Bowlby (1997) suggests, there are many emotional and political interests at stake if women come out of their position of inferiority (pp. 19-20). In my view, it is patriarchy's fear of losing its privileges that promotes the stigmatization of feminism. Bringing this issue to bear on the field of translation, patriarchy's fears may also explain the visceral hostility towards feminist interventions in translation. I am here using the word intervention as a synonym of manipulation. In the 1980s, publications such as Theo Hermans' (1985) The Manipulation of Literature and, slightly later, André Lefevere's (1992) Translation, Rewriting and the Manipulation of Literary Fame elicited analyses and translations which attempted to expose, i.e. make visible, the various types of 
translators' interventions in the source text. This intervention was called manipulation, a word which literally means to operate something with one's hands, but which, in other contexts, has accrued negative connotations suggesting a deceitful maneuver so that others may second our interests. The fourth definition of manipulation in the OED (2000) is actually: "the exercise of subtle, underhand, or devious influence or control over a person, organization, etc.; interference, tampering". Why would translators, feminist or otherwise, want to adopt this term with such negative overtones? I can think of various answers which are not necessarily incompatible with one another: 1 . they accept the term because it acknowledges the more or less considerable changes necessarily introduced by the translator's hand/intervention; 2 . because they want to denounce those translation practices which have implemented this manipulation without ever admitting it; 3 . because they want to produce a counter or reverse discourse which incorporates manipulation as a non-shameful practice, while dominant discourses persist in falsifying the translation process and present explicit manipulation as aberrant and dishonest behavior. This reverse discourse is implicit in titles such as José Santaemilia's (2005) Gender, Sex and Translation. The Manipulation of Identities. In summary, since feminist interventions pursue to dismantle patriarchy's oppressive ideology, the latter reacts with anxiety and indignation by deeming feminist manipulations as unethical. Feminism, in turn, both exposes the camouflaged prejudices in predominant translation practices and lays claim to a kind of mediation that starts by making the feminine visible and then moves on to construct an alternative and more just social order. In their denunciations of those masked manipulations which obey patriarchal criteria but pass off as neutral or free from any kind of ideological bias, a number of Canadian feminist translators, in the late 1980s, began to workoften in narrow collaboration with the women authors they translated or with the approval of feminist publishing houses - with the goal of making the feminine visible in the translated texts. The objective was not simply to highlight the linguistic gender or the feminine as a grammatical mark, but to show and promote women's participation in society. Women's contributions go unnoticed when we use conventions which either turn to the masculine grammatical gender to refer to a collective who comprises both men and women or employ vocabulary with no gender mark. Lotbinière-Harwood (1989) defined these Canadian translators' strategy as "a political activity aimed at making language speak for women" (p. 9).

\section{Galicia: feminist translation and the patriarchal nation}

For a discussion of the resistance met by feminist translation, I do not necessarily have to refer to the above mentioned Canadian precedents, because I have other, much closer, examples. Once again, it is relevant to specify where I speak from, as I do so from a cultural field, the Galician one, in which one case of feminist translation was followed by a law-suit and had a wide repercussion in the media. This is the case of the translation that the Galician writer and translator María Reimóndez made of the British author Mark Haddon's (2003) best seller The Curious Incident of the Dog in the Night-Time. For those who want to know more details about this case than I can possibly go into in this article, I recommend the article written by María Reimóndez (2009) herself for the journal Galicia 21 in the United Kingdom. In her article, the translator gives all the details of her conflict with the Galician publisher Rinoceronte Editora over her translation. Reimóndez describes her approach as containing "very mild feminist translation strategies" and as an illustration of "minimum intervention" (p. 85). Reimóndez's article also contains several statements that the publisher sent to the media. Concerning this same case, I would also like to recommend two articles by the academic Olga Castro $(2009,2013)$ published in the journals Quaderns (2009) and Gender and Language (2013). Apart from examining the power imbalance in the relationship between translation and para-translation, Castro analyzes 
the choices and decisions made in two translations of Mark Haddon's novel: the one registered with María Reimóndez's copyright and the one finally published by Rinoceronte and signed by Moisés R. Barcia, who is both a translator and the person in charge of the publishing house Rinoceronte. Castro's understanding of paratranslation as including the negotiations that take place between a translator and the publisher who commissions a translated text is in line with current approaches to the discipline of paratranslation which analyze "the impact of the aesthetic, political, cultural and social manipulations at play in all paratextual productions situated in and out of the margins of any translation" (Yuste Frías, 2012, p. 118). I would like to start by pointing out the long sequence of irregularities that occur-and I am afraid that this is not an exception in Galicia or the rest of Spain - when one takes up a literary translation. This bad praxis among professionals may surprise people like me who are not professional translators- i.e. I do not make a living from translations-but occasionally include the translating task among our academic activities in the field of philology. According to María Reimóndez's (2009) own published account, the case began in 2004 when Edicións Xerais commissioned her, by means of a verbal agreement, to translate Mark Haddon's The Curious Incident of the Dog in the Night-Time. Xerais had not previously applied for permission to translate Haddon's novel. We might expect from an experienced publishing house such as Xerais that contracts be written and translation permissions be obtained. When Reimóndez handed in her translation in 2007, another Galician publisher, Rinoceronte, had already bought the rights to translate Haddon's text. After some mediation between both publishers, Rinoceronte received Reimóndez's translation and, we would like to suppose that after its examination, offered the translator a contract. One may infer that Rinoceronte did not go through this translation with the necessary attention and rigor, since, if the publisher had detected, from the start, the particularities that he so much objected to later, both parties would have saved themselves much trouble. When María Reimóndez received the first proofs of the book, she noticed that there were a number of changes which contravened her feminist principles. According to Olga Castro's (2009) analysis, "a editora" [publishing house] was replaced with "os editores" [editors, in the masculine form], "a policía" [police] with "os policías" [policemen], "xente" [people] with "homes" [men], "a surfeira" [the female windsurfer] with "o surfeiro" [the male windsurfer], "mestra" [female teacher] with "profesor" [male teacher], "a dentista" [the female dentist] with "un dentista" [a male dentist] and, interestingly enough in the contrary sense, "mentireiro" [liar, in the masculine form] was replaced with "mentireira" [liar, in the feminine form]. María Reimóndez (2009) discusses the context of her expressions in the novel and claims that there is no basis to ascribe to them the masculine gender (or the feminine in "mentireira"), as the publisher and translator Moisés R. Barcia did (pp. 76-77). The ideological clash here is between a feminist approach, which desires to promote non-sexist language by increasing the visibility of the feminine gender and the patriarchal tenor of many linguistic and translation conventions. Eventually, the option that prevailed was the more powerful one. The publisher/translator's opinions appeared in the media and are reproduced ad litteram both by María Reimóndez and by Olga Castro in their articles. His views reveal the power relations between a publisher who commissions and pays for a translation and the translator who does the work and gets paid. The publisher claimed his right to have the last word as to the text to be published and suggested that, while Reimóndez was entitled to use non-sexist language in her creative writing, this was not applicable to her translation work. In fact, these arguments draw both on the traditional subaltern position of translation with respect to creative writing and on the translator's subordination to the ideological principles of the person who commissions a translation and has the last word. Another argument adduced by the publisher was that he actually checked with the author, Mark Haddon, if he agreed with the translator's options and 
Haddon did not. Apart from the difficulty of proving the exact terms of this conversation, it is again the criterion employed that interests me: Has the author, or the author's intention, primacy over the translator's interpretation? As a specialist in literary analysis, I am acquainted with the notion of the "intentional fallacy", which was coined by New Critics around the middle of the twentieth century (Wimsatt \& Beardsley, 1946) and refers to the primacy given to the author's alleged intention-I say alleged because in most cases one cannot prove it-over other meanings generated by the text itself, by the reading public or by society at large. For this reason, I object to the strategy of asking authors, in case of a discrepancy between the translator and the publisher, to determine which sex authors had in mind when using terms that are grammatically neutral. Neither are the authors' answers reliable nor are the authors the exclusive owners of meaning. Meaning is actually generated through complex social conventions, not on one individual's initiative. Olga Castro (2013) has also suggested that "collaboration with the author is an option, but should not be seen as an imperative" (p. 50). The publisher, Moisés R. Barcia, and the translator, María Reimóndez, could not eventually reach an agreement and the former canceled the contract, did not pay the translator for her work and published a translation under his own name (Haddon 2008). Among the many conclusions one can derive from this case, one is that publishers and translators should be better informed, and legally advised, with respect to the contracts that bind them: the publishers' rights to intervene in the translations and the limits and consequences of the translators' intellectual property. I would also like to suggest that more work needs to be done on the relationship between ethics and translation, on good praxis and the ethical principles that govern the various steps in the presentation of the translated text to the target culture. As for the issue of feminist translations, I share María Reimóndez's (2009) concern over the disrepute, mockery and insults addressed both to her and to this approach to translation (p. 84). I am similarly disturbed by the network of loyalties in the Galician literary field which privilege the important role of the publishing house Rinoceronte in national culture over the legitimate right to make a moderate contribution to non-sexist language. In small and vulnerable literary fields, such as the Galician one, alternative standpoints may sometimes be perceived as aggressions to national culture. Once again, comes to my mind the image of the beadle's "horror and indignation" in Virginia Woolf's A Room of One's Own, and I cannot help relating it to the visceral reaction of the media against María Reimóndez's moderately feminist translation. Like Woolf's narrator, the translator strayed from the path that a predominantly patriarchal institution had designed for her.

\section{Professionals, authors, academics, amateurs...}

The basic questions to be asked in the analysis of translation processes include: who translates, why, in which socio-cultural context, how, and for whom one translates. I have tried to answer some of these questions bearing in mind my own position in the Galician cultural context, but now I would like to turn my attention to the tensions between professional translators and those people from other professional fields who also engage in translation work. My views on this issue are no doubt influenced by the fact that I am a university professor of English literature who occasionally makes and edits literary translations. Therefore, I do not earn a living from my translations, nor am I a professor of translation studies. María do Cebreiro Rábade Villar (2009), who apart from being a poet is also a university professor of literary theory and an occasional literary translator has detected, in Galicia, a certain tension between the practice of translation by literary authors and that carried out by professional translators (pp. 62-63). She identifies a type of discourse which construes translations by literary authors as voluntaryist exercises done with little professional rigor. In what constitutes a teleological fallacy, these translations are perceived as the production of an early stage which should be left behind, i.e. as a signal of 
immaturity in the literary field which can only be overcome with the arrival of professional translation. Creative writers' translations are also often read as mere keys to understand their authors' literary creation, thereby reinforcing the subsidiary role of translation. According to Rábade Villar, advocates of professional translation maintain that only the latter can effectively contribute to the normalization and correct planning of the market of literary translations. To this view, the Galician poet objects that, both in the past and at present, creative writers' translations have coexisted with those by specialists, therefore suggesting that they can be simultaneous practices. She sagaciously adds that one cannot easily delimit and, even less, oppose a translator's various facets. It is not rare to find professional translators who become involved in other more or less similar tasks for which they also get paid, so I agree that it may be a chimera to try to oppose the multiple facets in a person's working life. Rábade Villar (2009) also insists on the role of resistance played by the author who intervenes in the cultural process by freely choosing a text for translation, i.e. regardless of the market's panning strategies (p. 65). I have some substantial reservations as to one's freedom in the choice of texts for translation, although I am ready to accept that a creative writer's translation proposal to a publisher may occasionally differ from the publisher's explicit or implicit translation policy. Rábade Villar does not refer to the additional value that a translation might be granted when signed by a literary author. On the contrary, she observes that, in a series of translations mentioned in her article, publishers did not particularly advertise them as the work of creative writers (p. 62). However, Olga Castro (2011) believes that a prestigious writer's name definitely has advertising power (p. 125). For this reason, I am of the opinion that translations by creative writers are inevitably embedded in market practices. The introduction of the gender dimension in this debate may prove illuminating. Since the Galician literary field is still profoundly patriarchal, the advertising power of a young female author's name is not likely to be as considerable as that of a male canonical writer. Although Rábade Villar illustrates her hypotheses with references to translations by, almost exclusively, male writers, the gender variable needs to be taken into account. The intersection of canon and gender is particularly revealing in a literary field in which established women writers such as Xohana Torres and Luz Pozo Garza have also been pioneer translators - Torres and Pozo Garza are two of the five female members, out of a total number of thirty, of the Royal Galician Academy, a predominantly male institution; the other three women at the RGA are the writer Fina Casalderrey, the film-maker and writer Margarita Ledo and the philologist Rosario Álvarez. Gender matters also because, as Olga Castro (2011) argues, there is a worrying imbalance between the large number of women registered as translators (one can even talk of the feminization of this profession) and the restricted number of women who participate in the more prestigious market of literary translations (p. 126). I would like to return now to the relationship between professional translations and the normalization and planning of the literary translation market. I wonder whether the discourses which promote this connection state an accomplished empirical fact and mean that, as a result of the university training of translators and their incorporation into the market of literary translations, one observes that publication strategies are now better planned and the market is thereby on the way to its normalization. Alternatively, one may interpret these discourses as a vindication that only professional translators have the legitimacy to plan the literary translation market. The latter attitude seems to me objectionable although, again, my own position as a nonprofessional probably affects my views. I subscribe Rábade Villar's disagreement with the teleological fallacy which presents non-professional translations as the product of an immature stage in the literary field. In fact, I would like to advocate that the various cultural actors (some more mercantile than others) should enjoy a degree of relative autonomy in their particular cultural projects. These projects can undoubtedly be assessed by other actors but should in no 
way be controlled and dominated by them. The gender question is also relevant here, as I hope to demonstrate. The Galician literary field, like so many others, has proved resistant both to the translation of women-authored texts and to the inclusion of women translators in its cultural projects. I am referring not only to the Galician nationalist movement in the 1930s (Ríos \& Palacios, 2005) but also to a later period, well into the 1980s, after the Statute of Autonomy (1981) and the Law of Linguistic Normalization (1983) were passed in Galicia. The spectrum of political regimes in Spain has been broad in the twentieth century: from the Spanish Republic (1931-1939) to General Franco's dictatorship (1939-1975) and, finally, democracy (1978-until present). The cultural projects of the various governments should have differed with regard to the inclusion of women in the sphere of translation, but resistance to change and the patriarchal inertia in the world of culture have been too strong. It is clear that one actor alone, even a powerful one such as a government's cultural policy, has not been able to put an end to these patriarchal inertias. However, Patricia Buján Otero and María Xesús Nogueira Pereira (2011) point out the importance of translations by Galician women writers who managed to make their way in a very hostile context. This shows that, contrary to dominant groups who resist women's participation, there are a number of loci of resistance and alternative initiatives which are more receptive to texts by female writers and translators. In their article, Buján Otero and Nogueira Pereira include the translation project run by the feminist writer and critic María Xosé Queizán for the collection of women's narrative "As Literatas" [women of letters] published by Edicións Xerais de Galicia. The authors praise Queizán's feminist commitment and wise choice of texts, the well-informed introductory essays and bibliography, the revealing and perceptive commentaries in the back cover, the book format of the collection and the translators' profiles (pp. 146-147). The translation project of this collection could then be presented as an example of good feminist translation praxis.

\section{On translation priorities and gender}

Alternative spaces which are receptive to women writers and translators are scarce, so differences inevitably arise as to which is the best and most effective strategy to adopt. Around 1992, the historian Xavier Castro and I proposed, to the publishing house Sotelo Blanco, the translation into Galician of a collection of short stories by Virginia Woolf. We had decided on her short fiction because much of it had not been translated into Spanish yet. Only the Barcelonabased publisher Lumen had produced the collection Una casa encantada y otros cuentos [A Haunted House and Other Stories] in a Spanish translation by Andrés Bosch (Woolf, 1979). One of the still on-going debates around Galician translations is whether they should or not duplicate what has already been translated into Spanish. As the writer and publisher Fran Alonso (2010) argues, an anomaly in the Galician reading public is that they read Galician writers in Galician but, for foreign literatures, they turn to Spanish translations (p. 38). Contrary to our expectations, the publishing house Sotelo Blanco suggested that, instead of Woolf's short stories, we should translate her novel To the Lighthouse, which already had two different Spanish translations: one by Antonio Marichalar in Buenos Aires reprinted in Barcelona (Woolf, [1938] 1984) and a second one by the acclaimed woman writer Carmen Martín Gaite in Barcelona (Woolf, 1986). The reason adduced by Sotelo Blanco for their choice was the importance of a canonical novel, as opposed to the marginal status of the short story genre. We eventually accepted the publisher's proposal and translated Woolf's novel (Woolf, 1993). I subsequently wrote two self-reflective analyses of the translation process of this novel (Palacios González, 1997, 1999). One of the conclusions I gather from this experience pertains to the above-mentioned notion of the relative autonomy of the various cultural actors, as this case proves that translators' priorities in their choice of a source text may not necessarily coincide 
with the publishers'. Moreover, gender intersects here with genre, as a woman writer is accepted in the target literary system as long as her text has uncontested canonical weight. Later, in 2002, I began to inquire about the possibility of editing a bilingual anthology of contemporary Irish women poets. From a university department of Galician philology I was told that, rather than translation from foreign languages, it was creative writing in Galician which should be encouraged at that stage. Gender intersected again with genre in these objections, as translation was viewed as a subsidiary strategy to be subordinated to the promotion of creative writing. In fact, both María do Cebreiro Rábade Villar (2009, p. 62) and Fran Alonso (2010, p. 36) have pointed out the dearth of translations of foreign poetry into Galician. Other cultural actors were, however, more receptive and even enthusiastic. I eventually edited this anthology of Irish women writers and translated the poems with the collaboration of the poet and professor of literary theory Arturo Casas (Palacios González, 2003). This publication was again followed by a self-reflective analysis of the translation process and the role played in it by gender (Palacios, 2008). It is very likely that both the growing visibility of Galician women poets since the 1990s and the longstanding cultural bonds between Ireland and Galicia contributed to the acceptance of our proposal by the publisher Follas Novas. This would illustrate Luise von Flotow's (2005, p. 39) emphasis on the importance of contexts and social relevance when it comes to authorizing certain translations. With this new experience, I could once again observe how the criteria for translation planning vary substantially depending on the institution involved and I believe that such a variety of views has more advantages than disadvantages. On the other hand, that the upsurge of women writers in Galicia should raise interest in women writers from a neighbor country reveals the non-negligible role of gender bonds. The third experience I would like to discuss here is connected with a collection of works-most of them translations-by women writers produced by the Equal Rights Department of the Galician government in collaboration with the publisher Sotelo Blanco. I reviewed (Palacios González, 2005) one of the first volumes in this collection "As Letras das Mulleres" [Women's Letters]: Mary Wollstonecraft's Vindicación dos dereitos da muller [A Vindication of the Rights of Woman] (2004). Apart from praising the rigorous introductory study by the philologist Dr. María Jesús Lorenzo Modia and remarking on the challenges in the translation of this kind of text, I expressed my surprise at the fact that the conservative government which sponsored this publication would participate in the dissemination of Wollstonecraft's still subversive feminist thought. This case made me think, over again, of the relative autonomy of the various cultural institutions. However, the first two volumes published in 2004-the other one was Christine de Pizan's (2004) A cidade das mulleres [Book of the City of Ladies] -were not granted the same warm welcome by other critics. Helena González (2004), a Galician literature professor, complained that: [...] it would be necessary to prioritize the translation of texts that are less archaeological and more updated and controversial, texts that are not always available in other neighbour languages (such as, in alphabetical order: Braidotti, Butler, Cixous, Collin, De Lauretis, Fuss, Haraway, Kaplan, Irigaray, Lorde, Mulvey, Rich, Sedgwick, Spivak [...]) (pp. 89-90, my translation). As I said above, the spaces for the incorporation of feminist discourses are scarce and polemics on which texts and authors may be the most appropriate is inevitable. If it were not distressful that women's works should have to elbow their way against one another, a controversy like this one could even generate entertaining satires like Jonathan Swift's Battle of the Books (1704) with its confrontation of ancients and moderns. One year later, the publishing house Sotelo Blanco asked me to write the introductory study of Virginia Woolf's (2005) essay Un cuarto de seu [A Room of One's own] for the aforementioned collection. Woolf's text was dexterously translated by the philology scholar Iria Sobrino Freire. I have had the opportunity to follow the reception of both the book and the collection, as I have been invited by various public libraries and their 
reading clubs to speak about Virginia Woolf. This public consists mainly of women readers who would not probably have approached the highly complex theoretical writings of Judith Butler or Teresa de Lauretis. Gender intersects, in this case, with the audience's cultural milieu, as some university professors prioritize cutting-edge female philosophers while reading clubs opt for classic women writers. One could then conclude that the audiences targeted by the various cultural institutions are as plural as these institutions' interests and ideological convictions. Like many other collections, this one of women's writing can and should be improved, but it is not rigorous to ignore its virtues regarding the excellence of the selected writers, the well-informed introductions and the meritorious quality of the translations. Galician governments and their ideologies have changed since 2004, but this collection has adhered to its declared aim to disseminate the contributions that women writers have made throughout history.

\section{Conclusions}

I would like to conclude this essay with a call to dialog and respectful collaboration among the various cultural actors so as to achieve a more balanced representation of women translators and woman-oriented translations in the literary market. Feminist translation theory is not likely to advance if it is not accompanied by a determined effort to produce more woman-centered translations. Simultaneously, women translators will do well in writing about their experience so that evidence can inform, and if necessary challenge, theoretical developments. I would also like to point out the urgency, for literature and translation scholars, to include the gender dimension in their analyses, so as to scrutinize how gender interacts with other variables such as national culture, literary canon, genre and audience. In connection with this, I have also proposed that a plurality and variety of translation actors - each of them enjoying some relative autonomy, targeting different audiences and setting different objectives-seems more appropriate than a translation industry controlled by one, no matter how enlightened and wellmeaning, single caucus.

\section{Acknowledgments}

This essay is part of a research project on contemporary women writers, funded by the Spanish Ministry of Economy and Competitiveness (FFI2012-35872).

\section{References}

Alonso, Fran (2010). Women, poetry, and publishing. In María Xesús Nogueira, Laura Lojo, \& Manuela Palacios (Eds.), Creation, publishing, and criticism. The advance of women's writing (pp. 35-39). New York: Peter Lang.

Arrojo, Rosemary (1998). The revision of the traditional gap between theory and practice and the empowerment of translation in postmodern times. The Translator, 4(1), 25-48.

Belsey, Catherine (1980). Critical practice. London: Routledge.

Bowlby, Rachel (1997). Feminist destinations and further essays on Virginia Woolf. Edinburgh: Edinburgh University Press.

Buján Otero, Patricia, \& Nogueira Pereira, María Xesús (2011). La (re)escritura de los márgenes. Traducción y género en la literatura gallega. In José Santaemilia, \& Luise von Flotow (Eds.), MonTI 3, Woman and translation (pp. 131-160). Alicante: Universidad de Alicante. English translation available at: http://repositori.uji.es/xmlui/handle/10234/38205?localeattribute=en. 
Castro, Olga (2009). El género (para)traducido: pugna ideológica en la traducción y paratraducción de 0 curioso incidente do can á media noite. Quaderns. Revista de traducció, 16, 251-264.

Castro, Olga (2010). Tradución, xénero, nación: cara a unha teoría e práctica da tradución feminista. Unpublished doctoral dissertation. Vigo: Universidade de Vigo.

Castro, Olga (2011). Traductoras gallegas del siglo XX: reescribiendo la historia de la traducción desde el género y la nación. In José Santaemilia, \& Luise von Flotow (Eds.), MonTI 3, Woman and translation (pp. 107-130). Alicante: Universidad de Alicante.

Castro, Olga (2013). Talking at cross-purposes? The missing link between feminist linguistics and translation studies. Gender and Language, 7(1), 35-58. Chamberlain, Lori (1988). Gender and the metaphorics of translation. Signs, 13(3), 454-472.

Daly, Mary (1985). Beyond God the father: Towards a philosophy of women's liberation. London: The Women's Press.

de Pizan, Christine (2004). A cidade das mulleres. (Introduction by Ma Carmen Pallares Méndez, Susa Blanco Montecelos, Trans.). Santiago de Compostela: Xunta de Galicia and Sotelo Blanco.

Delisle, Jean (2002). Portraits de traductrices. Ottawa: Les Presses de l'Université de Ottawa and Artois Presses.

Godard, Barbara (1988). Theorizing feminist discourse/translation. In David Homel, \& Sherry Simon (Eds.), Mapping literature. The art and politics of translation (pp. 49-51). Montréal: Véhicule Press.

Godayol, Pilar (2011). 'I like women': Regarding feminine affinities in translation. In Luise von Flotow (Ed.), Translating women (pp. 119-134). Ottawa: University of Ottawa Press.

González, Helena (2004). Dúas clásicas feministas en galego: ¿intervención ou arqueoloxía? Grial, 164, 89-90.

Haddon, Mark (2003). The curious incident of the dog in the night-time. Oxford, New York: David Fickling Books.

Haddon, Mark (2008). O curioso incidente do can á media noite. (Moisés R. Barcia, Trans.). Cangas do Morrazo: Rinoceronte Editora.

Hermans, Theo (Ed.). (1985). The manipulation of literature: Studies in literary translation. London: Crown Helm.

Lefevere, André (1992). Translation, rewriting and the manipulation of literary fame. New York, London: Routledge

Lotbinière-Harwood, Susanne (1989). About the her in Other. In Lise Gauvin, Letters from an Other (pp. 9-12). (Susanne Lotbinière-Harwood, Trans.). Toronto: Women's Press.

Manipulation (2000). Oxford English Dictionary (3rd ed.) (Online version March 2011. Retrieved 5 July 2011 from http://www.oed.com:80/Entry/113525).

Meaney, Gerardine (1993). Sex and nation: Women in Irish culture and politics. In Ailbhe Smyth (Ed.), Irish women's studies reader (pp. 230-244). Dublin: Attic Press. 
Miguélez-Carballeira, Helena (2004). The conflation of critical and translational paths in the Anglo-American reception of Mercé Rodoreda, Esther Tusquets and Rosa Montero. Unpublished doctoral dissertation. Edinburgh: University of Edinburgh.

Moi, Toril (1989). Feminist, female, feminine. In Catherine Belsey, \& Jane Moore (Eds.), The feminist reader. Essays in gender and the politics of literary criticism (pp. 117-132). Cambridge, Mass: Blackwell Publishers.

Nikolaidou, loanna, \& López Villalba, María (1997). Re-belle et infidèle o el papel de la traductora en la teoría y práctica de la traducción feminista. In Juan Pablo Arias, \& Esther Morillas (Eds.), El papel del traductor. (pp. 75-102) Salamanca: Ediciones Colegio de España.

Palacios González, Manuela (1997). Some considerations on the translation of Virginia Woolf's To the lighthouse into Galician. In Santiago G. Fernández-Corugedo (Ed.), Some sundry wits gathered together (pp. 177-181). A Coruña: Servizo de Publicacións da Universidade da Coruña.

Palacios González, Manuela (1999). The linguistic politics of translation: Translating Woolf into Galician. Virginia Woolf Miscellany, 54. (pp. 8-9).

Palacios González, Manuela (Ed.). (2003). Pluriversos: Seis poetas irlandesas de hoxe. (Manuela Palacios \& Arturo Casas, Trans.). Santiago de Compostela: Follas Novas.

Palacios González, Manuela. (2005). [Review of the book Vindicación dos dereitos da muller, by Mary Wollstonecraft. Introduction by María Jesús Lorenzo Modia. María Fe González Fernández, Trans. Santiago de Compostela: Xunta de Galicia and Sotelo Blanco, 2004]. Atlantis, 27(1), 151156.

Palacios González, Manuela (2008). The gender of translation: Irish poetry in Galician. Babel: Revue Internationale de la Traduction, 54(3), 268-280.

Patriarchy (2005). Oxford English Dictionary (3rd ed.) (Online version March 2011. Retrieved 5 July 2011 from bhttp://www.oed.com:80/Entry/138873\&gt).

Rábade Villar, María do Cebreiro (2009). Políticas e poéticas de segunda man: A espectralidade no proceso da tradución. Galicia, 21(A), 56-67.

Reimóndez, María (2009). The curious incident of feminist translation in Galicia: Courtcases, lies and gendern@tions. Galicia, 21(A), 68-89.

Ríos, Carmen, \& Palacios, Manuela (2005). Translation, nationalism and gender bias. In José Santaemilia (Ed.), Gender, sex and translation. The manipulation of identities (pp. 71-79). Manchester: St Jerome Publishing.

Santaemilia, José (Ed.). (2005). Gender, sex and translation. The manipulation of identities. Manchester: St Jerome Publishing.

Showalter, Elaine (1985). Introduction. The feminist critical revolution. In Elaine Showalter (Ed.), The new feminist criticism (pp. 3-17). London: Virago Press. Simon, Sherry (1996). Gender in translation. Cultural identity and the politics of transmission. London \& New York: Routledge.

von Flotow, Luise (2005). Tracing the context of translation: The example of gender. In José Santaemilia (Ed.), Gender, sex and translation. The manipulation of identities (pp. 39-51). Manchester: St Jerome Publishing. 
von Flotow, Luise (2011). Preface. In Luise von Flotow (Ed.), Translating women (pp. 1-10). Ottawa: University of Ottawa Press.

Wagner, Emma, \& Chesterman, Andrew (2002). Can theory help translators? A dialogue between the ivory tower and the wordface. Manchester: St Jerome Publishing.

Weedon, Chris (1987). Feminist practice and poststructuralist theory. Oxford: Basil Balckwell.

Wimsatt, William K., \& Beardsley, Monroe C. (1946). The intentional fallacy. Sewanee Review, $54,468-488$.

Woolf, Virginia (1979). Una casa encantada y otros cuentos. (Andrés Bosch, Trans.). Barcelona: Lumen.

Woolf, Virginia ([1938] 1984). Al faro. (Antonio Marichalar, Trans.). [Buenos Aires: Sur] Barcelona: Seix Barral.

Woolf, Virginia (1986). Al faro. (Carmen Martín Gaite, Trans.). Barcelona: Edhasa.

Woolf, Virginia ([1929] 1992). A room of one's own. [London: The Hogarth Press] Oxford: Oxford University Press.

Woolf, Virginia (1993). Cara ó faro. (Translation, introduction and notes by Manuela Palacios and Xavier Castro). Santiago de Compostela: Sotelo Blanco.

Woolf, Virginia (2005). Un cuarto de seu. (Introduction by Manuela Palacios González, Iria Sobrino Freire, Trans.). Santiago de Compostela: Xunta de Galicia \& and Sotelo Blanco.

Yuste Frías, José (2012). Paratextual elements in translation: paratranslating titles in children's literature. In Anna Gil-Bajardí, Pilar Orero, \& Sara

Rovira-Esteva (Eds.), Translation peripheries Paratextual elements in translation (pp. 117-134). Frankfurt am Main: Peter Lang.

Zaragoza Ninet, María Goretti (2008). Censuradas, criticadas... olvidadas: Las novelistas inglesas del siglo XX y su traducción al castellano. Unpublished doctoral dissertation. València: Universitat de València. 